\title{
PABLO DE ROKHA, UNA FORMA POÉTICA
}

POR

\author{
Fidel SePúlveda Llanos \\ Universidad Católica de Chile
}

Pablo de Rokha es uno de los poetas más grandes de habla hispana. Es una convicción que se ha ido asentando en nuestro espíritu a medida que hemos ido ahondando en el sentido de su creación. Creemos que el tiempo irá decantando su valía, perspectivizará su figura, por lo que fue y por lo que mostró como camino a las generaciones venideras.

Fue un poeta contradictorio. ¿Quién que esté vivo no lo es? Y Pablo de Rokha fue fundamentalmente vital. Son contradicción su ternura y su violencia, su individualismo y su socialismo, su visión futurista y añorante, su temporalidad y su eternidad, su ateísmo y su escatologismo, su alegría y su amargura, su solaridad y su soledad. Todos estos matices sin matices, extremados al extremo.

En pocas obras hay tanta autorreferencia como en la suya, y esto porque en pocos casos hay mayor consecuencia entre comportamiento vital y comportamiento creativo.

Para conocer su obra hay que conocer al hombre, y penetrar el sentido del hombre es penetrar en el sentido de su obra y de ahí ponderarla.

Pablo de Rokha se define:

Sí, sí, a mi corazón no lo tuercen los cantos, cultivo de espadas en terrenos de piedra y de hierro, y un gran animal sensual, comilón, dormilón y borracho, esto me define. ("Satanás")'

En este fragmento hallamos ciertas notas distintivas de la personalidad del poeta: lo abrupto, lo hedonista, lo anticonceptual; una estructura hondamente arraigada en lo concreto y en lo concreto áspero, violento, contrastado, vertido en una forma que constantemente anda buscando la consonancia para entrañar lo real en lo verbal.

En otra parte se definirá con estas palabras:

El hombre que rompe su época y arrasándola, le da categoría y régimen,

\footnotetext{
' Pablo de Rokha, Mis grandes poemas. Antología (Santiago: Editorial Nascimento, 1969) 61.
} 
pero queda hecho pedazos y a la expectativa;

rompiente de jubilaciones, ariete y símbolo de piedra, anhelo ya la antigua plaza de provincia y la discusión con los pájaros, el vagabundaje y

la retreta apolillada en los extramuros (231).

("Canto del macho anciano")

Los versos son elocuentes: contradicción con su época y consigo mismo. Han cambiado la edad y las ideas, pero no la fidelidad a su naturaleza eruptiva y nostálgica.

Este asedio al mundo y del mundo en su injusticia y sin sentido arrancará al poeta algunos de los versos más densos en la poesía castellana:

... yo soy el agonizante entre batallas, entre congojas, entre banderas y fusiles, solo, completamente solo, y lúgubre, sin editor, plagiado y abandonado en
el abismo (211).
("Canto del macho anciano")

En esta obra, transida de tristeza, agobio, desesperación, ya al final de su vida combatiente, hay acentos conmovedores.

La contingencia lo acosa y su estilo se impregna de ritmo e imagen que respiran la majestad bíblica de los profetas de Israel:

Si no fui más que un gran poeta con los brazos quebrados

y el acordeón del Emperador de los aventureros o el espanto del mar

me llamaban el alma,

soy un guerrero del estilo como destino, apenas,

un sonador acongojado de haber soñado y estar sonando,

un "expósito" y "apátrida"

de mi época, y el arrepentimiento

de lo que no hicimos, corazón, nos taladra las entrañas

como polilla, aserruchándonos (231).

("Canto del macho anciano")

La entonación, el ritmo majestuoso y dolorido de este fragmento, están sostenidos desde adentro por el sentimiento que se expande en versos prolongados en la revisión del pasado para segarse abruptamente en la vaciedad del presente.

La angustia, la soledad, el pesimismo acechan constantemente su obra. Estos sentimientos no son sino la consecuencia natural de su personalidad pura, auténtica, idealista en una sociedad donde lo ficticio, lo falso, lo acomodaticio están erigidos en valores que gobiernan la vida nacional. Pablo de Rokha no buscó el zigzagueo ni el camaleonismo ideológico y social, fue un individualista irreductible en un lugar donde el individualismo está condenado desde siempre al ostracismo. Para quien tenía tan clara conciencia de su valor, esta marginación por el único delito de no claudicar y transigir fue una herida de aquellos "puñales-amistad" que, al desangrarle lo fueron sumiendo en una atmósfera organizada como "Morfología del espanto". 
Su situación está expresada en estas palabras:

Soy el coordinador de la angustia del universo, el suicida que apostó su destino a la baraja de la expresionalidad y lo ganó, perdiendo el derecho a perderlo (211). ("Canto del macho anciano")

Su actitud es la del que se juega entero en la complejidad que implica una decisión definitiva.

Pocos como él han tenido tan clara la visualización de un destino y pocos también han sido tan fieles a esta marca del fatum como él lo quiso y lo pudo ser. Ésta es su realidad y éstas sus palabras:

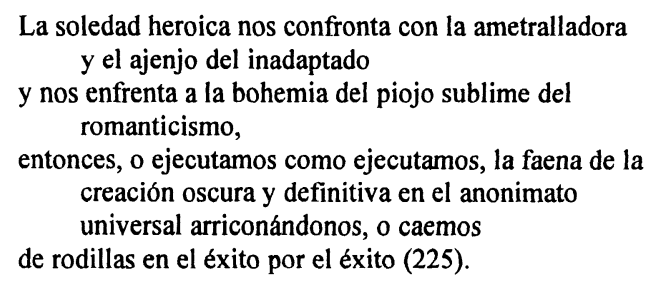

("Canto del macho anciano")

En el fondo siguió hasta su muerte su destino de inadaptado y romántico. Su vagabundaje proletario y militante fue sedimentando una amargura que lo hará decidir ya al final de su trayectoria hirsuta y acosada:

Y como ya todo es inútil, como los candados del infinito crujen en goznes mohosos, su actitud llena la tierra de lamentos (207).

("Canto del macho anciano")

Imagen magnífica que rezuma un pesimismo que, desde el ámbito personal, se derrama absolutizadora sobre el universo.

A la configuración de este cuadro en que soledad, angustia y pesimismo han puesto sus tintas más oscuras, han contribuido ciertos factores sociales contra los cuales se erizaban la epidermis y la médula del poeta. Aludamos siquiera a algunos, y en lo posible con el sentido que para Pablo de Rokha tenían. Rechaza a los:

hermafroditas con cierto talento de caracol haciendo un arte mínimo con pedacitos de atardecer amarillo,

y también: 
cuando en los andamios de los transatlánticos

como pequeños simios con chaleco despavorido, juegan

a la ruleta los grandes poetas de ahora (222).

("Canto del macho anciano")

En este fragmento, junto con valorar su intención, es preciso ponderar la ironía demoledora y restallante que vertebra las imágenes. En lo dolorido y en lo sarcástico, De Rokha posee un registro expresivo hasta ahora no escuchado en poesía castellana. Repárese en estos versos donde clarividencia conceptual y expresividad gráfica consolidan la repulsa contra aquellos que viven:

creyendo que el sueño es el hecho, que

disminuyendo se logran síntesis y categorías ... (225)

("Canto del macho anciano")

En el ámbito social, temática constante en el poeta, podemos recoger innumerables textos, pero en ánimo de escoger lo que, junto a su intención, implique objetivación creadora, valga el texto siguiente:

Arañando la propiedad privada, se agarran a la autoridad que otorga el dinero, exactamente como los murciélagos a las vigas de las ruinas ("Romance de emigraciones").

Este texto patentiza una hondura psicosocial que enraíza poéticamente su gráfica eficacia de génesis campesina en la imagen final. En ésta las asonancias están urdiendo una textura que consolida su nivel creativo. ${ }^{3}$

La temporalidad y la contingencia que lleva añeja es otro de los temas que recorren las páginas de sus obras.

A veces el tiempo es dimensión vital que pasa y pesa y abre un desafío. A tal perspectiva Pablo de Rokha responde:

Hay que poner el heroísmo de agonizar correctamente,

clavando los dedos de los ojos y su puñal en la

tiniebla acumulada,

sin abandonar la voluntad de podrirse (118).

("Moisés")

Otras veces se viste de cotidianeidad y desde la rutina envenena y lastra la existencia:

y todos nos cubrimos de coronas enlutadas, de leones de museo y oleografia,

\footnotetext{
2 Pablo de Rokha, Idioma del mundo. (Santiago: Multitud, 1955) 7.

${ }^{3}$ Texto complementario: "Sabíamos que seríamos abandonados de las familias y provincias del Universo, que la miseria nos iría mordiendo los talones del corazón y que nos quedaríamos solos para siempre nunca, solos, infinitamente solos frente a frente a la soledad en el abismo en donde insurgen suicidándose los que no lucraron con lo humano", 113.
} 
pues es el instante en que a la muchacha con la cual nos casamos le sale tiempo de pelo (171).

(“Sancho Díaz, capitán del Sur, define los actos mágicos")

¡Qué extraordinaria concretización del tiempo la de este texto en donde lo más hermoso de la vida, es socavado y preñado por Cronos!

En esta línea hay otros fragmentos, en que, a través de imágenes poderosas, insólitas, se nos entrega la dimensión temporal demoledora:

Como billete sucio en los bolsillos del pantalón del alma el tiempo inútil va dejando su borra de toneles desocupados y echando claveles de acaeceres marchitos a la laguna de la amargura (169).

También, y sobre todo, es realidad y deidad que abate y deja al ser empinado a la eternidad:

Pero ya nunca más contarás, ensangrentándote

el pellejo de emoción y poesía:

como cuando estabas tú asesinado por ti mismo,

e ibas cruzando las murallas, en las que el tiempo puso a orear la cabellera (119).

("Sancho Díaz, capitán")

Hermoso fragmento en que vocabulario y sintaxis se organizan en una andadura rítmica acorde con la idea de lo irremediable, añorado desde una perspectiva conflictiva.

Por el camino del tiempo se avanza al abismo de la eternidad y Pablo de Rokha, que fue temporalidad intensa y agobiada, urgencia y erupción, que dijo "el callejón de los ancianos muere donde mueren las últimas águilas", no pudo desviar su pupila frente al horizonte abierto e insondable en que la duración humana se apoza y se deslíe. En determinado momento dice:

Se apagarán todas las lámparas, gotea

el viento y el sol toma la forma de embudo (81).

("Moisés")

Su intuición rastreadora de expresiones empieza a perder concreción; se desrealiza en ansias de asir lo inasible: el abismo de la temporalidad que ya deja de ser tal.

En su poema "Jesucristo", es perceptible su esfuerzo por objetivar poéticamente la eternidad.

Afirmaría, que era de piedra y no era duro, no, no era duro; avanzaba la arista inmensa hacia afuera y, antes de hacerse efectiva, la había precedido la otra, y la otra de la otra, y la otra de la otra de 
la otra, de la otra, la simultaneidad sucesiva de este terrible espíritu en oleaje, ardiente de presente y olvidado, como la antigua cuna del $\operatorname{mar}(233)$.

("Matemáticas del espíritu")

Interesante fragmento que nos da varias claves para entender su sistema de poetizar. Primero hay evidente acierto en concretizar lo abstracto cuando en aquella "simultaneidad sucesiva" se entrega precisamente lo que es la eternidad, el tiempo interior del personaje del poema. Plegándose a esta intuición, anunciándola y preparándola, justifican su presencia las estructuras sintácticas (complemento de nombres) que al determinar, limitan, y al limitar intensifican en una secuencia espiritual que busca saetear el infinito.

Más adelante dirá en "Canto del macho anciano", "todo lo eterno me rodea, amenazándome y gritando desde la otra orilla", y en una imagen bellísima, "en lo alto del pasado el porvenir se derrama en pétalo de eternidad", que podría verse como una inversión de los valores al poner en el tiempo (la parte) lo eterno (el todo). También es susceptible de interpretarse como que en la temporalidad, ascendiendo en su conocimiento, vislumbramos otra realidad hermosa y delicada, la flor de la eternidad.

Esta preocupación escatológica se precisa en otros fragmentos:

Como los troncos añorosos de la vieja alameda muerta, lleno de nidos y panales,

voy amontonando inviernos sobre inviernos en las palabras ya cansadas con el peso tremendo de la eternidad (233).

("Canto del machado anciano")

Su temporalidad personal está referida a la eternidad y esta eternidad está difundida por todo el universo. Así se ve en su despedida de éste que es como su testamento poético:

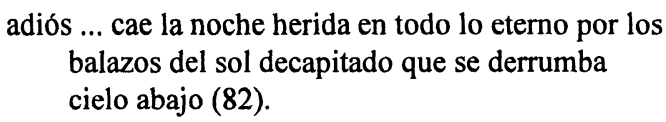

Hay realidades que han enraizado hondamente en Pablo de Rokha; realidades que afloran o subyacen y que polarizan su admiración o su dedicación en una primera época las figuras de Moisés y de Cristo lo llevan a dedicarles extensos poemas. Uno de los mejores momentos creativos lo genera la muerte de Cristo: "Murió así, porque es menester que mueran así los hombres - colinas, los hombres- murallas de la existencia" ("Matemáticas del espíritu") (87).

Es ésta una nueva poesía, diferente, donde la palabra se redime de su ancilaridad y, desde lo elemental, remonta su vuelo. Por esta vía va la forma creativa de de Rokha. En esta misma dirección está otro fragmento del mismo poema en que las cosas parecen ser ellas en su cotidianeidad y de hecho lo son; pero, a la vez, si miramos bien se han ido elevando, categorizando, absolutizando hasta desconocerle su rostro cotidiano:

Su actitud no venía, completamente, de su garganta o de sus entrañas, como el Dios de los océanos, no, venía de los trigales y los panales y los rosales y los vinedos galileos, 
venía de la esmeralda sonora del Tiberíades, venía de los caminos enarbolados de dulces sicomoros tristes y un sol cuadrado (108). ("Matemáticas del espíritu”)

Las estructuras se escanden en ritmo suavísimo, ondulan las palabras graves, enlazan sus manos las consonancias, matizan su movimiento los vocablos extensos evitando la monotonía y su remate insólito, contrastante, la potencia a la vez que hace evidente una estructura que, manejada a lo largo del poema, manifiesta la conciencia de forma que ya domina el poeta. Las imágenes son plenamente en sí, pero son más en su interrelación, pues todas están proyectadas teleológicamente a sugerir lo inefable en un mundo sin sentido.

Moisés es apreciado como líder que encarna lo misterioso y la vocación social. Extractamos un fragmento que ostenta características interesantes del estilo rokhiano:

Dice Jehová:

Por símbolos e imágenes infraconscientes, por sueños y por ecos de palabras, hablo con vosotros, mas al camarada Moisés le converso de amigo a amigo, porque lo estimo mucho, por hombre muy hombre y varón sustancial ... (229)

("Moisés")

Por ahí está la escala de valores de Pablo de Rokha. Por eso elige a tal figura para su poema. Es un hombre como quiso serlo él en su individualidad y en su proyección. Cuando Jehová expone su pensamiento, está hablando de Rokha y está hablando de Pablo de Rokha. Está, de otra parte, la manera de categorizar y jerarquizar el lenguaje coloquial.

En esta vía de autenticidad, menciona también a Cervantes y a Rabelais. Autenticidad y médula popular y hedonista.

Recuerdo al amigo Rabelais y al compadre / Miguel de Cervantes, tomando mi cacho labrado en los / mesones de las tabernas antiquísimas, las bodegas / y las chinganas, flor de invierno, y agarro / de la solapa de la chaqueta a la retórico-poética / del siútico edificado con escupitajos de cadáver, / comparto con proletarios, con marineros, con empleados, / con campesinos de tercera clase, mi causeo y mi botella, bebo con arrieros y desprecio a la intelectualidad podrida (220). ("Canto del macho anciano")

Ningún poeta chileno como Pablo de Rokha ha ahondado en la esencialidad telúrica, en su paisaje vegetal y humano, y de él ha exprimido los zumos de su cosmovisión y del lenguaje y forma poética que lo objetive creadoramente. Extractar esta simpatía suya sería antologar (valga la contradicción) toda su obra.

Pero él no nace de Chile, su ancestro es bastante anterior; viene de Heráclito y Demócrito, de La Biblia, y va pasando por toda la tradición cultural en lo que ésta tiene de plenitud vital fecunda y dramática. Por ello dice:

... ya no se trilla a yeguas ni se traduce a Heráclito (257); yo (voy) desentrafiando de los órficos, los pitagóricos o Heráclito el principio de la interpretación de los opuestos, o en los poetas-profetas de la Biblia, la antigua conmoción popular (257). Recuerda aquella combatividad indo-hispana de vértice en que se cruzaron, con espanto, las espadas de España y las hachas indianas, engendrándose entre la muerte (277). 
Valga como ejemplo de jocundidad dionisíaca esta estampa plena de dinamismo que retrata una de las manifestaciones populares chilenas con más arraigo e influencia en la psicología y sociología nuestra:

Gritando comedor abajo corrían esteros de pipeño encadenado comensales al oleaje, y los trasnochadores sacaban los paraguas, defendiéndose de la tormenta vitivinícola (219).

Este fragmento pertenece a la "Tonada a la posada de don Lucho Contardo", que es un templo a la chilenidad, no con el manoseo que esta palabra ha sufrido, sino en el hondo y verdadero que le asignaba Pablo de Rokha, limpia de folklorismos, neofolklorismos, snobismos, y mediocridades que se asimilan, hoy en día, bajo ese nombre. En ese sentido es que "todavía gotea la destiladera el sueño de los siglos en mi corazón del Huáscar". Sus aversiones y simpatías generan su vocación de poeta social, paladín de los desposeídos, de los humillados, de los explotados. Jamás dudó de su condición de gran poeta y que como tal tenía reservada la misión de crear un estilo nuevo, diferente, según su lema: a grandes masa, grandes formas de arte:

militante del lenguaje nuevo, contra el lenguaje viejo enfilo mi caballo (225).

("Canto del macho anciano")

Esta formulación escueta tiene modulaciones más amplias en innumerables creaciones. Vamos a citar las que, junto con este ideario mesiánico, comportan también su estilo característico, su forma específica:

El aullido general de la miseria imperialista da la tónica a mi rebelión, escribo con cuchillo, y con pólvora, a la sombra de las pataguas de Curicó, anchas como vacas, los padecimientos de mi corazón y del corazón de mi pueblo, adentro del pueblo y de los pueblos del mundo (316).

("Canto del macho anciano")

El enunciado tiene la fuerza expresiva característica del poeta y la reiteración enfatizadora, que es uno de los caracteres estilísticos más insistentemente trabajados en su poesía. Su obra hay que entenderla desde esta perspectiva. El poeta nos dice expresamente:

Extraigo mi idioma universal (como quien cosecha trigo o porotos)

del subsuelo social ...

estrujo la costumbre a la manera de los limones ...

y soy roto chileno que empuna la pluma como un corvo (257).

("Tonada a la posada de don Lucho Contardo") 
Tarea titánica la que se propuso Pablo de Rokha: ser el vocero, el que expresara sus anhelos, sus rebeliones, o su postración o fatalismo, no sólo expresar e interpretar, sino desalienar y conducir a su liberación, a la conquista de su destino personal y de clase.

El ser anárquico e iconoclasta que fue de Rokha no fue, sin embargo, una persona dispersa, derramada en la periferia, sino alguien duramente concentrado.

Que a lo largo de la vida tuvo campos magnéticos diversos y antitéticos no prueba sino su autenticidad e intensidad gnoseológica, vital. En esta trayectoria es posible visualizar una constante: su tránsito del caos al cosmos. Un cosmos amasado de contrarios, naturalmente, como le corresponde a un de Rokha. Pasará de lo religioso a lo profético, de lo profético a lo marxista, todo con una admirable entrega y devoción que le hacen entrañablemente estimable. El rechazo al reposo lo define. Al reposo y al conformismo. Esto hasta el último y tremendo acto con que cerró su existencia. Él mismo se perspectiviza:

sacando con mano temeraria y corajuda el orden de lo humano-cosmos desde el desorden del arcano-caos, el orden de lo humano-cosmos que es bello eterno, homogéneo o lo bueno sublime (130).

(Oceanía de Valparíso)

Hemos titulado este trabajo, "Pablo de Rokha, una forma poética". Cabe ya preguntarse qué es forma. Como gran parte de las palabras sometidas al trajín cotidiano, ésta ha sido desfigurada, gastada, y a lo largo de su vida ha tenido que pagar el precio de la existencia desempeñando variados oficios. En este trabajo quisiéramos reivindicar su categoría. Quisiéramos restituirle su destino de organizadora y rectora del cosmos.

En este sentido creemos que el ser no es sin la forma. Y, por otra parte, que la forma no es sin el ser. Así, en la medida en que algo sea más forma es más ser y en la medida en que algo sea más ser, necesariamente es más forma. Más forma implica en este aspecto más integración, más cohesión, más peculiaridad. Por tanto, no es acertado entender la forma desde afuera, por connotaciones accidentales o circunstanciales, sino desde adentro y esto explica y justifica lo accidental o circunstancial.

La forma supone, pues, un principio interno, generador y configurador de fisonomía, de morfología, de estructura. Éstas son manifestaciones, aspectos integrantes de la forma, pero no son la forma. Ésta está en la raíz y en el fruto, pero es más que ambos. La modalidad de la forma depende de este principio y su excelencia, titubeo o disolución, depende de la fuerza individualizadora, cohesiva o integradora, que supone toda forma.

Desde esta perspectiva es problemático hablar de forma extrínseca o exógena, o sea, forma provocada desde afuera. En todo caso, es necesario el principio cohesivo que impide la dispersión o desintegración y ahí, aunque reducida a su nimia expresión, está la forma.

La forma es originada desde adentro, es intrínseca o endógena.

Si hemos de suponer una jerarquía ontológica, y pareciera que no hay otra manera de entender el universo, estimamos que lo que cataliza la jerarquía, esta mayor o menor densidad de ser de lo existente, es la forma. De esta manera la escala de los seres estaría determinada por la gradación que va de la presencia a la ausencia de forma. En este sentido podemos hablar de formas insinuadas, germinales, y formas definidas, acabadas. Esto en la medida en que se puede hablar de lo definido y acabado en un mundo en que el devenir es el que 
ha originado y sigue generando nuevas formas, o perfecciona o deshace las existentes. Pero es que este devenir es, precisamente, conflicto y choque de formas opuestas que, en esta interrelación o interacción, ganan la posibilidad de superarse, asimilando nuevas y superiores calidades de ser.

En la realidad no hay formas acabadas, perfectas, pero es posible determinar una escala que va desde aquello que es yacente, que está detenido, que no tiene un principio interno que lo anime y lo lleve a integrar mayor cantidad y calidad, a otro que tiene en sí su propio principio que le permite ser más o ser menos ser. Esta autodirección la podemos apreciar en los seres. De la piedra al vegetal, del vegetal al protozoo, de éste al crustáceo y así en toda la escala animal, está demostrando una escala de forma. Considerando la forma artística como algo humano, del hombre, por el hombre y para el hombre, debe tener una constitución análoga a la de éste. Deberá ser una estructura con un sistema que le posibilite cohesión, integración, peculiaridad, irreiterabilidad. Deberá tener un principio subordinante, organizador, a cuya dirección se acojan y plieguen todas sus facetas de acuerdo a su calidad. En calidad de organismo con su principio constitutivo, está regido por leyes que guiarán su existencia y comportamiento.

La estructura que posibilite la vida y supervivencia dependerá de la magnitud y complejidad del organismo a que debe servir. Si este principio rector no es capaz de garantizar tales condiciones, si no genera una estructura o ésta no es idónea, querrá decir que no hay forma o hay una defectuosa, que ha dejado al ente entre el caos y el cosmos.

El ente poético supone la puesta en existencia de algo que antes no existía; supone la creación, no la copia o reflejo o expresión de lo ya existente. Para tal efecto debe operarse una reorganización del universo. Cada metáfora desencadena una reacción en cadena que pone en peligro la estabilidad del mundo. Podrá ser una tempestad en un vaso de agua o en el mar océano; pero, si es realmente una metáfora, es una revisión y revolución en el orden y leyes del universo. Supone poner en existencia y funcionamiento un cosmos que se rige por otras leyes que las del mundo físico y del mundo práctico. Los elementos que constituyen este ser ya no son los mismos del mundo real y las relaciones que entre ellos se entablan, tampoco. La creación en este sentido es un "milagro" y, como milagro, es inexplicable por la razón. De una parte supone un extraerle a las cosas su principio constitutivo para organizar un nuevo ser, pero sin que la cosa así despojada pueda reivindicar su principio, que ya quedó definitivamente incorporado a otro sistema de existencia. Esto de una parte. De otra, los "espíritus" de las cosas tampoco pueden recordar su origen e iniciar el retorno, pues caen en otro sistema de convivencia o coexistencia que encauza y organiza su energía y comportamiento. Esto es maravilloso, misterioso y peligroso. Peligroso para el cosmos práctico, para el demiurgo que lo genera y para las cosas mismas que participan de este cosmos.

Para el cosmos práctico, porque podría generalizarse este procedimiento y con ello finaría su existencia. Para el creador, porque puede caer en la tentación del poder por el poder. Para las realidades integrantes de este cosmos, porque pueden ensimismarse ovidando su origen y su vocación de servicio. Porque este cosmos que acabamos de esbozar tiene una misión: servir al hombre.

Dados estos principios y a partir de ellos, nos aventuramos a la búsqueda de la forma en Pablo de Rokha. Por los fragmentos hasta ahora expuestos creemos que es evidente 
que su obra tiene una fisonomía, y una peculiarísima fisonomía. Inconfundible en cuanto a intención e inconfundible en cuanto a realización. Pero la forma es peculiaridad, pero no sólo eso. Es integración, cohesión, ritmo y vida. La forma poética es cosmos, organicidad.

Pablo de Rokha, conceptual y poéticamente, manifestó su voluntad de forma. En este trabajo nos ceñimos a su expresión poética. Pero intención no implica realización. Son innumerables los textos aludibles para ejemplificar esta conciencia y voluntad de forma. Por vía de ejemplo veamos algunos:

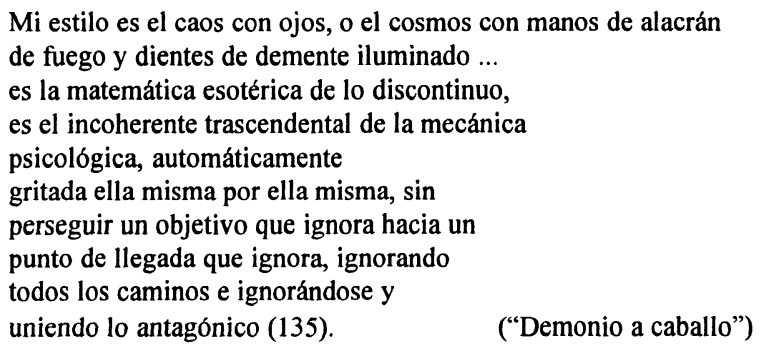

Grave problema plantea este fragmento. El caos es la negación de la forma. ¿Cómo, entonces, crear una forma poética del caos? ¿Pudiera darse una expresión del caos? Esta expresión, ¿sería? O sea, tendría forma, pero al tener forma no estaría reflejando el caos. Lo estaría aludiendo conceptualmente, pero no lo estaría reflejando estructural y orgánicamente. Esto es un poco lo que sucede con este fragmento de Pablo de Rokha. El fragmento tiene sentido y su sentido no es caótico, que sería lo contrario del sentido.

Afortunadamente, no toda voluntad de forma tiene esta dirección, que vendría siendo, en este caso, voluntad de no forma. Así dice poco más adelante:

Saquemos del horror de la sustancia social el horror de la belleza total, creemos el hombre, forjemos el arte con lo mágico, lo adivinatorio, lo trágico y elemental en la unidad abismal de la persona metafórica (226).

(“Demonio a caballo")

Este programa ya es más inteligible y, al parecer, más realizable en teoría y en la práctica. Así al menos en Pablo de Rokha, gran parte de cuya creación podríamos entenderla escrita bajo este propósito. Más adelante agrega "del dolor del error salió la poesía" y esto es bastante más claro y verdadero por lo que a su obra respecta. En otra parte expresa:

Las escrituras que son un sueño sujeto a una cadera inexorable e imagen que nadie deshace ni comprendió jamás, arrastran las napas de sangre que corren por debajo de la humanidad y al autodegollarse en el lenguaje, organizándolo, el lenguaje mío me supera, y mi cabeza es un montón de escombros que se inciendan (249). 
Hay en su concepción un sentido romántico de la creación, de "inspiración", de enajenación, que hace que la obra vaya mucho más lejos de lo que el autor se propone. De otro lado está aquella corriente subterránea (¡lo sub- o inconsciente colectivo!) que origina sus saltos imprevistos, sus relaciones insólitas, sus imágenes desconcertantes, la atmósfera casi onírica de gran parte de su obra.

Precisando más su sentido de creación poética en "Oceanía de Valparaíso", dice:

El poema es lenguaje de imágenes, es decir lenguaje de catástrofes e idioma metafórico y catastrófico, no racional $y$, estando versificado o no versificado es poema el poema, el cual genera no juicios, estilo, y la prosa lógica es conceptual y funcional, como razonamiento solo, y no existe lo prosaico poemático, porque la imagen no se raciona como la botella de vino al imbécil o el pienso al asno, las cosas colgadas sobre el abismo, como racimos de relojería atroces, le pertenecen trágicamente y épicamente al sistema planterario del cuotidiano del calendario sideral de Valparaíso.

Este fragmento es paradigmático, en cuanto teoría y praxis. Desde luego no es racional ni lógico; se pasa de una imagen a otra sin anuncio y sin que lo práctico pueda hallar una razón que explique tal procedimiento.

Su poesía busca ser "el retrato de la sociedad y sus contradicciones" y:

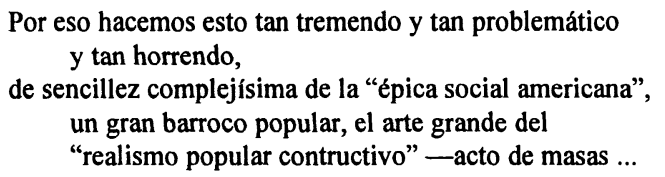

(“Oceanía de Valparaíso")

Éste es el ideal poético forjado por Pablo de Rokha. A nosotros no nos interesan los nombres como a él no le interesaban los "géneros", aunque cuando denomina su estilo poético recurre a ellos. Pero sí es claro que tenía conciencia clara de la dificultad de su empresa. Se trataba de una "sencillez complejísima". ¿Alcanzó este ideal en su obra? Dificil responder en forma categórica pero en la medida en que es posible una apreciación, creemos que la respuesta es afirmativa para buena parte de su labor poética. Aunque habría que señalar más complejidad que sencillez (319).

¿Cómo se organiza y produce la forma poética en de Rokha? Desde una perspectiva analítica deberíamos comenzar por el vocabulario, por el estrato léxico.

\footnotetext{
${ }^{4}$ Mis grandes poemas 35 . Texto complementario: "los cantos de mi lengua tienen ojos y pies ... Ojos y pies ... Crean ... Algo que antes, no estaba en la tierra, prolongan mi anatomía terrible hacia lo absoluto, aún existiendo independientemente, jtocad su cuerpo, tocad su cuerpo y os ensangrentaréis los dedos miserables! ..."
} 
Este aspecto es claro en su intuición selectiva. El poeta no opera con todas las palabras, sino con aquéllas que generan atmósfera. Configura un sistema en que las palabras tienen cada cual una temperatura y fisonomía inconfundibles. A veces, es el conjunto el que homogeniza un ambiente. Otras, es una palabra la que, al reiterarse, va polarizando y catalizando intencionalidad, también sucede que, entre sí, están creando campos magnéticos que tironean dialécticamente su sentido.

Por vía ejemplar extractamos algunos fragmentos. Su naturaleza hirsuta -al del poeta - siente la prisión y lo feble del idioma y procede a composiciones que, de algún modo, aprehendan su intención. Por ello es que, combinando, crea términos como "gringohampón-ladrón-matón" o "aventurero nacional-provincial-departamental" o "artesanía popular-manual-provincial".

Otras veces procede a la categorización de lo coloquial popular. Así dice: "ejemplo de carajo patronal y gran mala persona" en donde se opera un rescate y redención del lenguaje común.

Ejemplo de palabras claves que irradian su temperatura y fisonomía a todo un período lo podemos hallar en el "Romance de emigraciones", en que la palabra "desvencijado", trabajada como paladeo, desde lo sensorial ahonda lo esencial, en tal forma que, cuando nos hallamos con cláusulas como "bastón de mendigo sin mendrugo ni parientes que siquiera lo escupan", los sonidos resuenan, se aliteran y, desde su sintonía fónica, tienden la red que enlaza la imagen. En esta veta fónica expresiva, en "Canto llano al potencial económico de Chile" encontramos este pasaje que "sindudamente" esta laboreado con este interés: "La veta de plata pura y el reventón del rosetón de cuarzo, el rosicler de los concentrados maravillosos saturados del platino lunar, duro y feroz como colmillo de oligarca". Asonancias, consonancias, densificaciones oclusivas, erizan el período de durezas aristadas que siluetizan lo humano.

Cuando añorando el pasado dice: "los rotos del Norte Grande, bien comidos y bien bebidos, no tenían la esqueletosa condición de hoy por hoy", está asignando al neologismo su auténtica misión: eficacia expresiva y significativa. En nivel semejante se halla la "filibusterocracia feudal-patronal". Y por este camino, bordean el abismo, llega el lenguaje de la chilenidad en que no hay veda para lo coprolálico, que no es coprolalia sino rastreo de realidad. En este ímpetu de rusticidad es que le está permitido decir: "iqué gran patada le pegaríamos a la vida en todo el hocico!", o retromirar su patria diciendo:

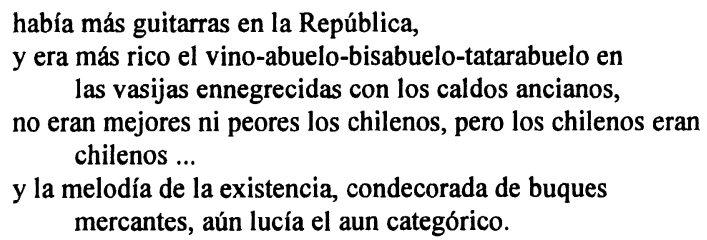

("Tonada a la posada")

\footnotetext{
${ }^{5}$ Idioma del mundo 93. "Juntitos los guachitos del Señor de la costa chilena, se agarran a la telaraña espectacular de los peñascos rojos".
} 
Este "aun" absolutizado irradia resplandores desde su posición solitaria e inesperada.

De los múltiples facetas que supone un estilo macizo y vertebrado como el de de Rokha, no podemos silenciar su tono hiperbólico y desorbitado y en el que, por contraste, cuando aparece el diminutivo, aparece con una frescura y ternura tal que pocos, poquísimos, escritores castellanos podrían comparársele. ${ }^{6}$

Entre innumerables, no resisto la tentación de transcribir uno, verdadera joya de delicadeza y fuerza regada por una ternura irrestañable:

Cuando los álamos se revisten de infinito terciopelo amarillo $\mathrm{y}$, estremeciéndose, sollozan a la caída del sol, en el funeral de la tarde, la vacada muge en los palacios de invierno y la peonada ensangrentada de espanto, aprieta un pan de afrecho contra las costillas, para la sopita de la familia menesterosa (21).

Bello fragmento en que el siginficante se pliega al significado con una ponderación de la gradación rítmica y conceptual que sólo puede organizar un gran poeta. Es un perfecto sistema de valores integrados.

Pero no sólo el estrato léxico es el que ha templado el crisol del poeta. Como habrá podido apreciar el lector, las estructuras idiomáticas también han sido sometidas a una rearticulación, retorciéndose hasta la exacerbación con la complementación, dislocándose en tensiones de sentido desbordadas, constreñidas a sistemas de convivencia lastimadores de la rutina, que estimamos inoficioso ejemplificar, alabados después en otros poetas, lo que provocará ácidas y desencantadas expresiones al poeta tan injustamente preterido.

Entre los procedimientos poetizadores, el contraste, la antítesis, tiene una presencia constante. No podía ser de otra manera en un hombre que hizo de la contradicción su eje conductual. Así en "Los gemidos" escribe: "y se abre a ras del infinito, el fabuloso, el fabuloso capullo del trueno". En el ejemplo son las palabras las que generan el contraste. Otras veces son la situaciones:

Cargamos a la espalda todo el dolor del hombre y además el muerto, ¡ay! ... ¡Qué frío! ... ¡trae el brasero, las mantas y el vino, mujer! ... (83).

Uno de los efectos más perseguidos en su obra es el énfasis. A la consecución de este objetivo obedece la reiteración que se abre en infinitos matices: énfasis que a su vez obedece a la consecución de lo absoluto y lo absoluto de lo absoluto, como diría don Pablo, en aquella forma tan dilecta del complemento del complemento. Otra manera de enfatizar es la contraposición, que, contraponiendo, destaca. Muchas veces la repetición presenta la estructura polisindética:

\footnotetext{
${ }^{6}$ Idioma del mundo 11.
} 
Grandes águilas, grandes páginas de fuego y piedra, y piedra y fuego, llanto y fuego, y sueño $y$ fuego, y barro y fuego, y un hombre enfermo que consigue la salud del mundo (147),

se dice en su poema "Jesucristo".

Esta persecución del énfasis arboriza en un estilo hiperbólico y no pocas veces tremendista. Frecuentemente lo superlativo cristaliza escarchando el matiz.

El carácter atropellado y torrencial que tiene la enumeración rokhiana también se trasmite a sus imágenes, eje de su sistema poético. No me cabe duda de que las imágenes más poderosas, violentas y restallantes de la poesía chilena están en este poeta. Su proliferación lo define. Son imágenes desorbitadas normalmente, pero así deben ser, conocido el propósito creativo del autor.

Es extraordinaria la conjunción de fuerzas que compactan la sustancia de sus imágenes.

Por vía ejemplar, consigo éstas, elegidas al azar en una página: "Las esperanzas despedazadas de los náufragos", "el sollozo final de los últimos pájaros de las islas", "el ladrido de los ladrillos de las tumbas", "el gritazo de la ceniza del Dios único". Capacidad evocativa del significado y carnadura sugestiva del significante están exigidas hasta sus últimas reservas. Ahí está el secreto del acento vibrante, caldeado al rojo vivo de la poesía del profético e iconoclasta Pablo de Rokha.

No es un secreto el origen de esta potencia. Echemos a caminar la memoria por las palabras que siguen y llegaremos a una de sus fuentes:

Pequeña eres, pero las más rotundas catedrales se te parecen exactamente, su espanto clemental tremendo, del bosque enorme, y caverna de Dios, su atmósfera de relámpagos, su actitud de mundo y de fruta de sol te rodean, a ti preñada, embarazada de iluminación y congoja (158). ("Únicamente")

Otras veces dirá, contemplándose a la distancia:

Muchacho de provincias tremendamente crecido de acacias y puñales,

en ti se levanta el clamor de los muertos

con la gran lágrima estrangulada en la garganta (279).

(“Sancho Díaz, capitán”)

Pero si Pablo de Rokha es capaz de recordar "cuando los borrachos aran los barrios con los colmillos", también es capaz de traer entre "los potreros entrebolados de mariposas" al "quetehue huacho en su canción de cántaro de agua" y desde ahí instaurar un verdadero "arte de pájaros" como lo evidencian estos versos: 
Adentro del recuerdo de potrero de las inmensas pajareras aquellas perdices de entonces, tiraban el silbido regional contra las pircas y los pajonales de los totorales de Vichuquén, y el zorzal más frutal que los membrillos, que traía en el corazón, cantaba la canción de Yungay, pidiendo dulces alfalfales verdes,

el llanto de oro de las diuquitas dominaba la madrugada, cuando las calandrias remecían su boldal nativo, mientras los chincoles y los charcanes, acarreaban su atadito de música a la cocina, $y$ el tordo, tal como un ruiseñor venido a menos, vestido de negro raído, enamoraba a la loiquita ensangrentada o a una chincola rubia, y los pidenes de los atradeceres tocaban sus acordeones mínimos (221).

("Tonada a la posada de don Lucho Contardo")

En este fragmento campea la existencia de un universo poético en que cada sonido cristaliza en un acorde. Mundo de transparencia y resonancia que nadie que haya conocido su tierra podría dejar de reconocer y aspirar.

Quizás por esto su poesía no oxigena las arterias de más chilenos y quizás por esto, también, cada día los chilenos son menos chilenos.

A pesar de todo y recordando "las vegas nativas de los costinos en donde impera la lenteja real de Jacob y Esaú y la pregunta blanca de la gaviota", o añorando que:

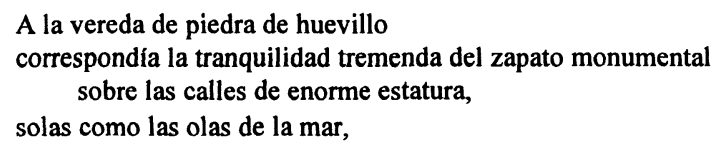

su poesía tiene autonomía y categoría y el ritmo vital de lo auténtico.

Autenticidad que no esconde "las duras lágrimas del varón [que] revientan ardiendo, como piedras tremendas en el desamparo y en el abandono total" y que, dirigiéndose a su compañera, declara: "hoy escribo con versos quebrados tu actitud de oceanía".

Por esta vía estamos llegando a la zona de la más alta poesía que no excluye el compromiso, sino que lo supone. En la medida en que el poeta está comprometido, lo está como poeta, es decir, como demiurgo, padre y responsable de la plenitud de la criatura que ha salido de su costilla, de su corazón.

Él ha escarmenado la materia, la ha moldeado, amasándola le ha comunicado su calor, la ha transminado de vida, de su vida, y como tal no puede quebrantarla, curvarla a la ancilaridad panfletaria.

En Pablo de Rokha tenemos compromiso y tenemos poesía. A veces es compromiso solo y a veces es poesía comprometida.

El compromiso le impone desde adentro su forma, su forma de ser como poesía, y alta poesía es ésta: 


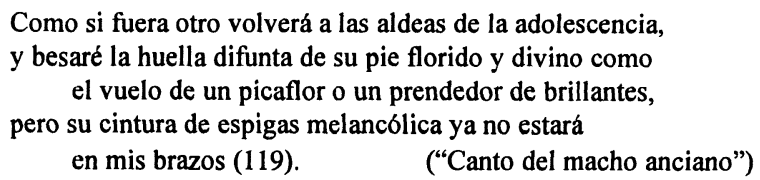

El ritmo ondula moldeado por el sentido y las cosa, desde su concreción y pesantez, se transfiguran iluminadas por el aire dorado del recuerdo. Cada sentimiento exige un ritmo para nacer, desarrollarse y permanecer en la existencia. Así en Pablo de Rokha. Repasemos, si no, "Escritura de Raimundo Contreras". Hay una sintaxis simple, hilvanada, sin nexos, espaciamiento rítmico, archipiélago de intuiciones, sin trama, sorprendiendo lo virtual, imaginería transparente, balbuceo de comprensión, cosmos campesino hondo, simple, sensitivo, elemental. En lo fenoménico, lo esencial.

Al lado de esto, el ritmo pujante, reiterado, ardorosamente renovado de este fragmento:

rempujando amargos carros de tercera, rempujando

empeños,

rempujando cantinas, rempujando abismos,

rempujando palomas,

abandonados (171).

("Poesía funeraria")

Sentimiento y ritmo se corresponden y por ello tiene vida este poema. Partiendo de un detalle concreto, de una situación rutinaria, de una voz popular ("rempujando"), de lo humilde, como la vida, se va gestando y gastando la vida. Hay un ímpetu en el inicio, que se renueva y renueva y renueva hasta que adviene la laxitud.

Otro caso, con elementos todavía más simples que el anterior, lo oscuro, lo enigmático, lo absurdo es un caballo:

que corre y corre y corre y corre y corre hacia y contra la suciedad iluminada, en la cual naufraga

la existencia humana (127). ～("Sancho Díaz, capitán")

El movimiento rítmico desbocado, impulsado por la reiteración verbal y renovado cada vez por el polisíndeton, va "hacia y contra" y a partir de ahí se derrama, horizontalizado en el fracaso. El ritmo es el organizador de la forma.

Los casos anteriores tipifican el ritmo de oleaje en renovado remontar que, abatiéndose, va a morir en la playa.

Veamos ahora lo contrario:

Por aquellos años, la pena que dolía se comía, remojándola en ácidas lágrimas pálidas.

Lo áspero y ríspido del sentido está encarnado en la triple cadena de esdrújulos. Antes, la vivencia se escande en secuencia de graves. La conciencia se eriza en esdrújulos. La intuición, por el ritmo en el ritmo, se estructura en forma. 
Pablo de Rokha aspiró y logró, en buena medida, crear una estructura diferente de acuerdo a las diversas formas que se fraguaban en su espíritu. En "Jesucristo", por ejemplo, trabaja la imagen en un sentido sugerente, suave, transparente, y los remates son contrastados, violentos, inesperados. En "Demonio a caballo", su estructura se arma con los núcleos trimembres tan caros al poeta y que le permitían vertebrar sus poemas de fuerza, dinamismo y relieve.

\section{Mi ser consciente ruge cuando piensa, brama cuando habla, gime cuando crea, cargado de instinto, discontinuidad y síntesis (171).}

Al lado de esto, la atmósfera delicada de "Círculo", de aire tierno y evanescente, pero insistentemente veteado de turbulencias que lo perfilan inconfundible. "Romance de emigraciones" se estructura con período largo, con poración-período, a la manera del planosecuencia filmico. A través es la repetición enrarecedora la que cosmogoniza lo humano y humaniza lo cósmico. Las relaciones entre los elementos zigzaguean en discurrir alógico, como corresponde a su índole de forma a la manera de las napas subterráneas con las que se identifica.

Los grandes poemas de Pablo de Rokha hay que entenderlos precisamente como eso: macroestructuras que viven y se comportan en su núcleo y en su periferia con sus propias leyes y sistemas. Es distorsionar su dimensión y su perfil aplicar la perspectiva del relojero de los poemas reducidos a esta forma poética eruptiva o panorámica. Como los grandes organismos, cuesta que estos poemas se pongan en movimiento, homogenicen su temperatura, cobren su ritmo, perfilen su espíritu.

Alguien señaló la semejanza que habría entre la forma de Pablo de Rokha y la de los grandes muralistas mexicanos. La relación es certera en cuanto a morfología y también en cuanto a los prerrequisitos para percibir su modo de existencia. Ambos viven y se entienden partiendo de los ancestros, de las raíces. Quien no se haya embebido de aquella cosmovisión y nutrido de sus esencias, no podrá gozar de esta forma violenta, contrastada, gigantesca. Es un mundo primitivo y mágico que requiere una perspectiva de igual índole para ser comprendido y valorado.

Es una forma en la cual no hay cabida para la filigrana y la orfebrería. Todo es ciclópeo y monumental. Pablo de Rokha, por temperamento y por voluntad, salvo contados y excelentes momentos, se ha vedado al reino de lo simétrico y delicado. La fuerza define su forma poética. A veces, en los instantes decisivos, no acierta con la expresión y se desbordan las expresiones arañando el sentido. Allí están su mérito y su debilidad. Más vivencia que conciencia. Más emoción que reflexión. Más sentimiento que entendimiento. Más conmoción que intuición. Esto si se mira al detalle. Pero en lo hondo, en lo hondo de lo hondo, si se pondera cada obra como totalidad, es difícil hallar otra creación poética donde esté sedimentada tanta conciencia, reflexión, entendimiento e intuición de lo nacional y popular.

Para terminar, pensamos que no hay forma y fondo en la obra de arte. Que cuando se está hablando en estos términos no se ha enfocado el problema correctamente. Mirar la obra artística como un tema susceptible de vestirse con tal o cual ropaje es estar hablando 
de otra cosa muy distinta al arte. ¿Cómo entender la creación en su génesis o en su versión última haciendo tal escisión? ¿Es que el fondo es artísticamente mientras no está objetivado? ¿Es que la forma es siendo forma de nada? Concretamente, ¿es que Pablo de Rokha poeta es porque fue un ser violento, valiente, contradictorio? ¿Una poesía es violenta porque su fondo es violento o sólo lo es en tanto cuanto está encarnada y su carnadura es violenta?

Aludamos sólo a la obra más representativa de la creación de Pablo de Rokha, junto con el "Canto de macho anciano": "Epopeya de las comidas y de las bebidas de Chile".

Pensamos que esta obra ostenta una forma acabada. Las comparaciones se desplazan desde el guiso a lo animado, de lo animado a lo humano, de lo humano a lo divino. Las relaciones son una sucesión continua, sin remanso para el respiro, en que las evocaciones temáticas y los elementos que las constituyen se encadenan en asociaciones urgidas por el azar y, sin embargo, no hay desorden, no hay capricho, no hay gratuidad: hay un ritmo que organiza y metaboliza lo heteróclito.

Se trata de una poesía donde Dionisos sentó sus reales y conjuró todo lo incitante, evocador y hedonista. Esto genera una ansiedad por laudar y pletorizar que eclosiona metáforas, imágenes, sinestesias, hipérboles. Hay dispersión, pero es la dispersión del deslumbramiento, es dispersión que, dispersando, concentra, condensa. Períodos disyuntivos o polisindéticos en este caso obedecen a la misma ley: sirven al estado emotivo. Quien piense en gastronomía no ha entendido nada. El poema no es para gusto de gourmet. Es poesía en que se exprimen las esencias más populares de lo popular con adjetivación y adverbialización magnificadora. Esta magnificación va avanzando a la veneración, a lo sagrado. El poema es un connubio de la carne y el espíritu. Tierra y hombre están en trance de consumación, lo humilde y precario tiene la vetustez de lo patriarcal, la vetustez y la grandeza.. Esa vetustez sacra está entregada en un ritmo reiterativo y envolvente que acopia materiales y los transmuta en sangre poética que vitaliza toda la forma. Una continua antropomorfización destila vitalidad y gracia. Conjunción de aliteraciones, consonancias o asonancias internas asocian evocaciones y convocan presencias.

¿Por qué un pacato maniqueísmo ha de desterrar la comida y la bebida del reino de la poesía, de lo heroico y lo sagrado? No fue así en la antigüedad y sólo una visión mutiladora del hombre ha podido relegar esta realidad a lo hilarante, grotesco y plebeyo. No fue así antes ni en lo humano ni en lo divino. No debe serlo ahora si queremos recuperar al hombre para lo humano.

Esta epopeya amalgama el tono normativo con el argumental y laudatorio como en dilatada sobremesa que discurre sobre los manteles bordados de la chilenidad. Con ello se está logrando plenamente la categorización de lo chileno-cotidiano-coloquial.

Se trata de una forma en que el léxico rotundo y pleonástico, el ritmo acesante y desenfrenado va incorporando una hilera de nombres propios anodinos, de lugares escondidos e insignificantes, de condumios y potajes "ordinarios" y localistas, y con todo, y por eso mismo es la poesía chilena que ha calado más hondo en la peculiaridad de lo chileno y desde esta peculiaridad cala en lo permanente humano que no existe en abstracto, sino en versiones únicas e irrepetibles y, sin embargo, concordantes. Aquí comida y bebida son el elemento catártico que genera situaciones, y las situaciones conflictos y los conflictos esencias. Y ¿qué le pedimos el arte sino que a través de su lógica alógica, de su razón arracional nos entregue, objetivado y vivo, lo entrañadamente humano? 
Esto está, y en forma eminente, en Pablo de Rokha.

El espíritu de cada uno de los rincones de este "país de rincones" y el espíritu de la nación en el pasado y presente y desde éstos en el futuro. Esta realidad no es posible entenderla si no es por su forma, forma que es el fondo, fondo que es la forma. Forma original, inconfundible, autónoma, con la autonomía que se dan las altas creaciones del espíritu y que se la dan porque, creando, han ganado el derecho a dársela. Se gana el derecho a crear. También se gana el derecho a entender. En esto estamos. No lo gana quien quiere, sino quien puede. Lo último no depende de nosotros. Lo primero sí. En eso estamos. 